\title{
Purification of Metallo- $\beta$-Lactamase CcrA from Bacteroides fragilis with Salting-out Method
}

\author{
Cheng-Cheng Liu, Le Zhai, Ying Shi and Ke-Wu Yang* \\ Key Laboratory of Synthetic and Natural Functional Molecule Chemistry; Ministry of Education; College of \\ Chemistry and Materials Science; Northwest University; PR China
}

\begin{abstract}
A simple and effective salting-out method was developed for the purification of the metallo- $\beta$-lactamase CcrA from Bacteroides fragilis based on the plasmid pMSZ02, in which the crude protein secreted into growth medium was precipitated by $80 \%$ sulfate saturation of the medium and purified with Q-Sepharose to offer pure CcrA with yield of $20.1 \mathrm{mg}$ per litter medium. The dependence of the amount of protein precipitation on sulfate saturation was investigated, which showed that more than $80 \%$ sulfate saturation resulted the maximum protein precipitated. The purified CcrA was evaluated by steady-state kinetics using penicillin $G$ and cephalothin $V$ as substrates, which showed the $K_{m}$ values of $68 \pm 2$ and $17 \pm 2 \mu M$ and $K_{\text {cat }}$ values of $63 \pm 1$ and $102 \pm 3 S^{-1}$, respectively. The comparison with the data of the protein from literature method showed that the salting-out method was viable, and it could be useful for the purification of other proteins secreted into growth medium.
\end{abstract}

Key words: metallo- $\beta$-lactamase CcrA, plateau elution profile, purification, salting-out method

\section{INTRODUCTION}

As one of the most successful classes of antibiotics, $\beta$-lactam antibiotics, which inhibit a transpeptidase involved in biosynthesis of cell wall, have been widely used in the clinical bacterial infection therapy (Tipper 1979). However, the widespread use of $\beta$-lactam antibiotics has put tremendous selective pressure on bacterial strains to devise the mechanisms to escape the lethal action of the drugs (Wang and Benkovic 1998). The most common and efficient strategy employed by the strains to resist the $\beta$ lactam compounds is the expression of $\beta$ lactamases (Bebrone 2007). There are currently more than 300 known $\beta$-lactamases, which have been divided into four classes (Ambler 1980; Bush 1989a; Bush 1989b; Bush et al. 1995; Rasmussen 1997; Bush 1998). Classes A, C and D are serine- $\beta$-lactamases, which employ an active-site serine to catalyze the hydrolysis. The remaining class B enzymes, often called metallo- $\beta$-lactamases (MPL's), require 1, or $2 \mathrm{Zn}$ (II) ions bound to their active sites for full catalytic activity (Payne 1993; Cricco et al. 1999; Crowder and Walsh 1999). M $\beta$ L's are especially worrisome as they can hydrolyze all known $\beta$-lactam antibiotics and there is no known clinically useful inhibitor for them (Periyannan et al. 2006).

Bacteroides fragilis is one of the most important pathogens in polymicrobial infections in humans. The isolate is responsible for most anaerobic infections in humans and induces the bacteremia that is associated with an average mortality of $27 \%$ (Brook 1989). Unfortunately, there is no effective therapy for B. fragilis infections so far due to its resistance to $\beta$-lactam antibiotics, tetracycline, clindamycin, and metronidazole (Rasmussen et al.

*Author for correspondence: kwyang@nwu.edu.cn 
1993). The prime mechanism for $\beta$-lactam antibiotics resistance is the production of $\mathrm{CcrA}$, a B1 subclass $\mathrm{M} \beta \mathrm{L}$, which hydrolyzes almost all the known cephalosporins, carbapenems, and penicillins antibiotics and is not effectively inhibited by the marketed $\beta$-lactamase inhibitors such as clavulanic acid, sulbactam, and tazobactam (Yang et al. 1992; Bush et al. 1993; Rasmussen et al. 1994). In order to design clinically useful inhibitor for CcrA, one important step to aid in this task is to elucidate the catalytic mechanism of this enzyme, which requires large amounts of active and soluble CcrA for biochemical and structural studies.

M $\beta \mathrm{L}$ CcrA used in early biochemical and structural researches has been over-expressed in $E$. coli as inclusion bodies and the active CcrA is obtained by renaturing the $8 \mathrm{M}$ urea-solubilized inclusion bodies in metal ion-containing buffer (Yang et al. 1992; Concha et al. 1996; Crowder et al. 1996). This preparation process is subject to the aggregation of the enzyme at high protein concentration and is not reliably reproducible (Wang and Benkovic 1998). For this reason, Z. Wang successfully constructed a new overexpression plasmid pMSZ02 for soluble CcrA. With this over-expression system, the enzyme is secreted into the growth medium in an active and soluble form with a consistent yield of 20-25 $\mathrm{mg} / \mathrm{L}$. Due to this, the plasmid pMSZ02 is widely used in the subsequent biochemical and structural studies (Yanchak et al. 2000; Periyannan et al. 2006). But the purification process requires a long period in the concentration of medium to concentrate the proteins. In this work, based upon the plasmid pMSZ02, a simple and effective method for the purification of M $\beta \mathrm{L}$ CcrA from $B$. fragilis was evaluated. Also, the kinetic parameters of the purified CcrA were evaluated in comparison with the enzyme purified by the traditional method.

\section{MATERIALS AND METHODS}

\section{Materials}

Plasmid pMSZ02, containing the gene that encoded for CcrA, was kindly provided by Professor Michael Crowder at Miami University. BL21 (DE3) E. coli cells were purchased from Solarbio. Tryptone and yeast extract were obtained from Oxoid Ltd. Penicillin G, cephalothin V and isopropyl-1-thio- $\beta$-D-galactopyranoside (IPTG) were purchased from Sigma. Chromatographic column XK16, Q-Sepharose and Sephadex G-75 were purchased from GE healthcare. All chromatographic steps were carried out on a GE AKTA purifier system at $4^{\circ} \mathrm{C}$. The electronic absorption spectra were recorded on Agilent 8453 $\mathrm{UV}-\mathrm{Vis}$ spectrometer.

\section{Over-expression of CcrA}

The over-expression of M $\beta \mathrm{L}$ CcrA was carried out as previously described (Wang and Benkovic 1998). Briefly, the plasmid pMSZ02 was transformed into BL21 (DE3) E. coli cells, the colonies containing the plasmid were used to inoculate $50 \mathrm{ml} \mathrm{LB}$ medium containing $25 \mu \mathrm{g} / \mathrm{mL}$ kanamycin. After the pre-culture grew overnight at $37^{\circ} \mathrm{C} ; 10 \mathrm{~mL}$ of the culture was transferred into $5 \times 1 \mathrm{~L}$ of LB containing $25 \mu \mathrm{g} / \mathrm{mL}$ kanamycin. The cells were grown at $37^{\circ} \mathrm{C}$ with shaking until the cells reached an O.D. $600 \mathrm{~nm}$ of 0.6 , subsequently cooled to $25^{\circ} \mathrm{C}$ in water bath for $15 \mathrm{~min}$. The production of CcrA was induced with $1 \mathrm{mM}$ of IPTG at $25^{\circ} \mathrm{C}$ for $20 \mathrm{~h}$. The cells were removed by centrifugation $(20 \mathrm{~min}$ at $8,671 \mathrm{~g})$ at $4^{\circ} \mathrm{C}$ and $5 \mathrm{~L}$ of supernatant was combined.

\section{Purification of CcrA by salting-out method}

With salting-out method, CcrA was purified by precipitation of the protein in ammonium sulfate solution. Briefly, ammonium sulfate was added slowly to $2 \mathrm{~L}$ of the supernatant with stirring. After continuously stirring for $30 \mathrm{~min}$ and keeping at $4^{\circ} \mathrm{C}$ for $60 \mathrm{~min}$, the precipitated protein was collected by centrifugation (30 $\mathrm{min}$ at $17,696 \mathrm{~g}$ ), and re-dissolved in $30 \mathrm{~mL}$ of ice cold $30 \mathrm{mM}$ Tris$\mathrm{HCl}$, pH 7.6, containing $100 \mu \mathrm{M} \mathrm{ZnSO}_{4}$. The crude protein solution was dialyzed versus $3 \times 2 \mathrm{~L}$ of the same buffer during a 36-h period, followed centrifuging (45 min at $41,731 \mathrm{~g}$ ) to remove any precipitate. The clear supernatant was loaded onto a 20×200 mm Q-Sepharose column and eluted with a plateau elution profile as shown in Figure 1, where the salt concentration was kept constant at $80 \mathrm{mM}$ and $160 \mathrm{mM} \mathrm{NaCl}$ for 60 min each (flow rate of $2 \mathrm{~mL} / \mathrm{min}$ ). Fractions containing CcrA were identified by sodium dodecyl sulfate polyacrylamide gel electrophoresis (SDS-PAGE). Those fractions exhibiting bands around $26 \mathrm{kDa}$ with more than $95 \%$ purity were pooled and concentrated in an Amicon concentrator equipped with an YM-10 membrane. Protein concentrations were determined using Beer's law and an extinction coefficient of $39000 \mathrm{M}^{-1} \mathrm{~cm}^{-1}$ at $280 \mathrm{~nm}$. 


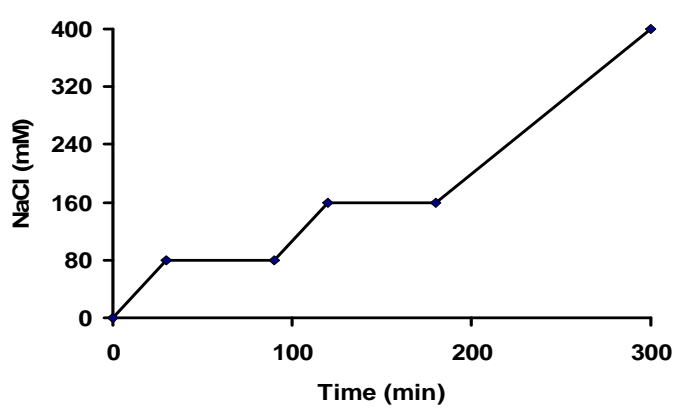

Figure 1 - Plateau elution profile for higher purification of CcrA (flow rate was $2 \mathrm{~mL} / \mathrm{min}$ ).

Purification of CcrA by concentration method The purification of CcrA by the concentration method was carried out as previously reported (Wang and Benkovic 1998). A $2 \mathrm{~L}$ of supernatant was concentrated to about $30 \mathrm{~mL}$ using an Amicon concentrator equipped with an YM-10 membrane. The crude protein solution was dialyzed against $3 \times 1 \mathrm{~L}$ of $30 \mathrm{mM}$ Tris- $\mathrm{HCl}, \mathrm{pH} 7.6$ containing 100 $\mu \mathrm{M} \mathrm{ZnSO}$, during a 36-h period and centrifuged for $45 \mathrm{~min}$ at $41,731 \mathrm{~g}$ to remove any precipitates. The supernatant was loaded onto a $20 \times 200 \mathrm{~mm}$ QSepharose column. Bound proteins were eluted with a linear gradient of $0-400 \mathrm{mM} \mathrm{NaCl}$ in 30 $\mathrm{mM}$ Tris- $\mathrm{HCl}, \mathrm{pH} 7.6$, containing $100 \mu \mathrm{M} \mathrm{ZnSO}_{4}$, at a flow rate of $2 \mathrm{~mL} / \mathrm{min}$. Fractions containing CcrA were combined and concentrated to about 10 $\mathrm{mL}$ using an Amicon concentrator equipped with an YM-10 membrane and then loaded onto a $30 \times 700 \mathrm{~mm}$ Sephadex G-75 column for further purification. Fractions containing pure CcrA were identified by SDS-PAGE.

\section{Steady-state kinetic studies}

Steady-state kinetic studies were conducted on an $\mathrm{UV}$-Vis spectrophotometer at $25^{\circ} \mathrm{C}$. The buffer used in experiments was $1 \times$ MTEN buffer $(50 \mathrm{mM}$ MES, $25 \mathrm{mM}$ Tris and $25 \mathrm{mM}$ ethanplamine containing $100 \mathrm{mM} \mathrm{NaCl}, \mathrm{pH}$ 7.0). $K_{m}$ values were determined by varying the substrate concentration from 0.1 to $10 K_{m}$. The hydrolyses of antibiotics by CcrA was monitored by detecting the formation of the product at $235 \mathrm{~nm}$ for penicillin $\mathrm{G}$ and $265 \mathrm{~nm}$ for cephalothin $\mathrm{V}$, and the absorbance data were converted into concentration data using the extinction coefficient $\Delta \varepsilon=-936$ and $-2447 \mathrm{M}^{-1} \mathrm{~cm}^{-1}$, respectively. The kinetic parameter $K_{m}$ and $K_{c a t}$ values were determined by least-squares fitting of the velocity data at different substrate concentrations to the hyperbolic Michaelis -
Menten equation using CurveFit. All the experiments were repeated for three times.

\section{RESULTS AND DISCUSSION}

The pMSZ02-transformed $E$. coli cells were grown to the mid-log phase and induced by $1 \mathrm{mM}$ IPTG for $20 \mathrm{~h}$ at $25^{\circ} \mathrm{C}$ to avoid the cell lysis. Most of the protein was found in the growth medium in a soluble form (Fig. 2), which made its purification easier than renaturing the $8 \mathrm{M}$ urea-solubilized inclusion bodies. However, the concentration of the large volumetric growth medium needed $48 \mathrm{~h}$ to concentrate $2 \mathrm{~L}$ of medium to $30 \mathrm{~mL}$ with an Amicon concentrator. A Q-Sepharose column was used for the purification of CcrA. The column was eluted with linear gradient formed by $500 \mathrm{~mL}$ of the starting buffer and $500 \mathrm{~mL}$ of $30 \mathrm{mM}$ Tris$\mathrm{HCl}, \mathrm{pH} 7.6$, containing $100 \mu \mathrm{M} \mathrm{ZnSO}{ }_{4}$ and 400 $\mathrm{mM} \mathrm{NaCl}$ at a flow rate of $2 \mathrm{~mL} / \mathrm{min}$. The protein was eluted out within 80 to $160 \mathrm{mM} \mathrm{NaCl}$. The collected fractions containing CcrA were concentrated and loaded on Sephadex G-75 column to give purified protein with a yield of $20.3 \mathrm{mg}$ per liter of growth medium.

Salting-out method makes it easier to purify the CcrA. The dependence of protein aggregation on the saturation of ammonium sulfate was investigated. Different quantities of sulfate were dissolved slowly into $10 \mathrm{~mL}$ of medium to prepare the solutions with 10-100\% saturation, stirred for $30 \mathrm{~min}$ to dissolve the salt sufficiently, and kept at $4^{\circ} \mathrm{C}$ for $60 \mathrm{~min}$ to make protein precipitate efficiently. The precipitates were collected by centrifugation and re-dissolved in $10 \mathrm{~mL}$ of icecold $30 \mathrm{mM}$ Tris- $\mathrm{HCl}$ containing $100 \mu \mathrm{M} \mathrm{ZnSO}_{4}$, $\mathrm{pH}$ 7.6. The amount of precipitated protein was quantified by the absorbance at $280 \mathrm{~nm}$. 


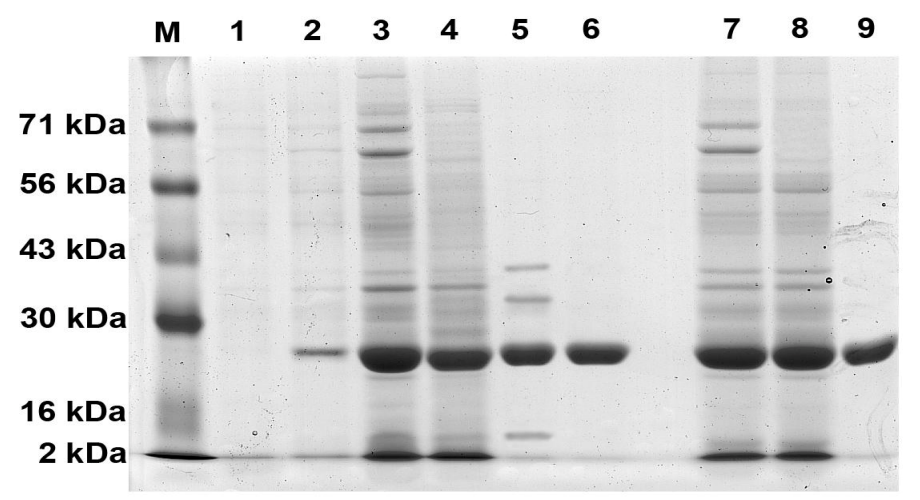

Figure 2 - SDS-PAGE gel of over-expression of CcrA and comparison of salting-out and concentration purification method. Lane M, molecular mass markers; lane 1, growth medium before induction; lane 2, growth medium after a $20 \mathrm{~h}$ induction with $1 \mathrm{mM}$ IPTG; lane 3, crude protein after concentration; lane 4, crude protein after dialysis into low salt buffer; lane 5, CcrA eluted from Q-Sepharose column; lane 6, pure CcrA eluted from Sephadex-G75 column; lane 7, re-dissolved crude protein precipitated by ammonium sulfate; lane 8, re-dissolved crude protein after dialysis into low salt buffer; lane 9, pure CcrA eluted from Q-Sepharose column with the plateau elution profile.

The dependence of the amount of precipitated protein on sulfate saturation is shown in Figure 3. The protein precipitation increased with the sulfate saturation, $20 \%$ protein precipitation with a $20 \%$ sulfate saturation, around $40 \%$ protein precipitation with a $40 \%$ saturation, and up to almost all protein precipitation with the higher than $80 \%$ saturation, when there was almost no protein left in the supernatant. The SDS-PAGE of the precipitated protein is shown in Figure 4. The results indicated that adding sulfate of $80 \%$ saturation could make almost all the CcrA precipitate.

The purification of CcrA was conducted with Q-
Sepharose column. The crude protein was dialyzed against $3 \times 2 \mathrm{~L}$ of low salt buffer for $36 \mathrm{~h}$ to lower the salt concentration and the column was equilibrated with $80 \mathrm{mM}$ salt for $120 \mathrm{~mL}$ to make some hybrid-proteins eluted. CcrA was eluted with a gradient salt concentration from 80 to $160 \mathrm{mM}$ and held in $160 \mathrm{mM}$ with $120 \mathrm{~mL}$ of the eluant, which allowed CcrA to elute out completely. Using this method, without Sephadex G-75 column for further purification, pure CcrA was isolated with the yield of $20.1 \mathrm{mg} / \mathrm{l}$ medium, which was good match with the yield from the concentration method.

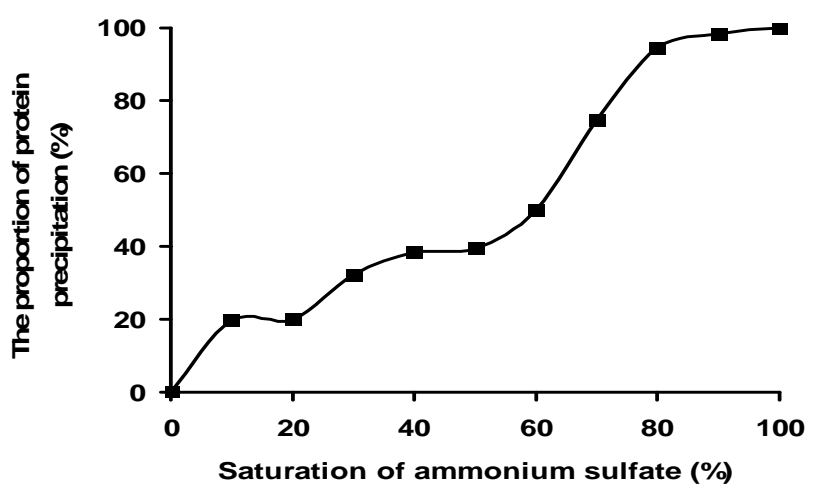

Figure 3 - Dependence plot of the proportion of protein precipitation on saturation of ammonium sulfate in the growth medium. 


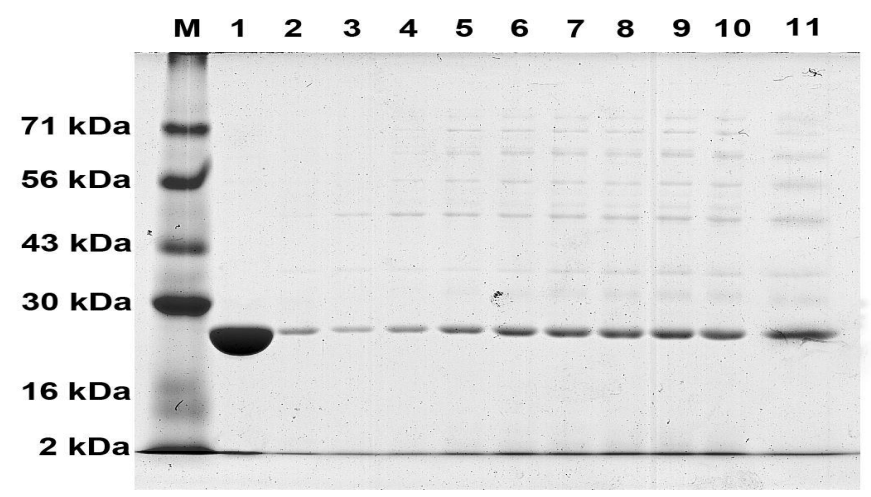

Figure 4 - SDS-PAGE gel of proteins precipitated in 10-100\% ammonium sulfate saturation of the growth medium. Lane M, molecular mass markers; lane 1, pure CcrA; lane 2, proteins precipitated by ammonium sulfate with $10 \%$ saturation; lane 3, $20 \%$; lane 4, $30 \%$; lane 5, $40 \%$; lane 6, $50 \%$; lane 7, $60 \%$; lane 8, $70 \%$; lane 9, $80 \%$; lane 10, $90 \%$; lane 11, 100 $\%$.

The steady-state kinetics was employed to assay the CcrA purified with salting-out method. The resulting kinetic parameters are listed in Table 1. Using penicillin $\mathrm{G}$ and cephalothin $\mathrm{V}$ as substrates, the $K_{m}$ and $K_{\text {cat }}$ values were $68 \pm 2$ and $17 \pm 2 \mu \mathrm{M}$, and $63 \pm 1$ and $102 \pm 3 \mathrm{~S}^{-1}$, respectively.
These kinetic parameters were matched with the kinetic data of CcrA from the concentration method using the same antibiotics as substrates listed in Table 1, which indicated that the saltingout method was viable for the purification of the proteins secreted into growth medium.

Table 1-The kinetic parameters and yields of CcrA purified by the salting-out and concentration method.

\begin{tabular}{cccccccc}
\hline \multirow{2}{*}{ Method } & \multirow{2}{*}{$\begin{array}{c}\text { Yield } \\
(\mathbf{m g} / \mathbf{L})\end{array}$} & \multicolumn{2}{c}{ Consuming time $(\mathbf{h})$} & \multicolumn{3}{c}{ Steady-state kinetic parameters* } \\
\cline { 3 - 8 } & & $\begin{array}{c}\text { Concentration or } \\
\text { salting-out }\end{array}$ & $\begin{array}{c}\text { Isolation by } \\
\text { chromatography }\end{array}$ & $\begin{array}{c}\boldsymbol{K}_{\boldsymbol{m}} \\
(\boldsymbol{\mu M})\end{array}$ & $\begin{array}{c}\boldsymbol{K}_{\text {cat }} \\
\left(\mathbf{s}^{-1}\right)\end{array}$ & $\begin{array}{c}\boldsymbol{K}_{\boldsymbol{m}} \\
(\boldsymbol{\mu M})\end{array}$ & $\begin{array}{c}\boldsymbol{K}_{\text {cat }} \\
\left(\mathbf{s}^{-1}\right)\end{array}$ \\
\hline Concentration & 20.3 & 48 & 18 & $77 \pm 8$ & $51 \pm 1$ & $23 \pm 3$ & $97 \pm 2$ \\
Salting-out & 20.1 & 2 & 5 & $68 \pm 2$ & $63 \pm 1$ & $17 \pm 2$ & $102 \pm 3$ \\
\hline
\end{tabular}

*All the experiments were repeated for three times.

\section{CONCLUSION}

This study reported a very simple and effective method for the purification of the matallo- $\beta$ lactamase CcrA from B. fragilis based on the plasmid pMSZ02, in which the crude protein was precipitated by $80 \%$ sulfate saturation of the growth medium and purified with Q-Sepharose to offer pure CcrA with the yield of $20.1 \mathrm{mg} / 1$ medium. The dependence of the amount of protein precipitation on sulfate saturation was investigated, which showed that more than $80 \%$ sulfate saturation made the maximum protein precipitated. The purified CcrA was evaluated by steady-state kinetics using penicillin $G$ and cephalothin $\mathrm{V}$ as substrates to give the $K_{m}$ values of $68 \pm 2$ and $17 \pm 2 \mu \mathrm{M}$ and $K_{\text {cat }}$ values of $63 \pm 1$ and $102 \pm 3 \mathrm{~S}^{-1}$, respectively. These kinetic parameters, when compared with the data from the concentration method showed that the salting-out method was viable and it could be probably be useful for the purification of other proteins secreted into the growth medium.

\section{ACKNOWLEDGMENTS}

We are grateful to Professor Michael W. Crowder of Miami University for providing the overexpression plasmid pMSZ02 for CcrA. This work 
was supported by grants (to K. W. Y) from National Natural Science Fund of China (20972127), Doctoral Fund of China (200806970005), Natural Science Fund of Shaanxi Province (2009JM2002) and Key Fund for International Cooperation of Shaanxi Province (2010KW-16).

\section{REFERENCES}

Ambler RP. The structure of $\beta$-lactamases. Phil Trans $R$ Soc Lond B. 1980; 289(1036): 321-331.

Bebrone C. Metallo- $\beta$-lactamases and their superfamily. Biochem Pharmacol. 2007; 74(12): 1686-1701.

Brook I. Pathogenicity of the Bacteroides fragilis group. Ann Clin Lab Sci. 1989; 19(5): 360-376.

Bush K. Classification of $\beta$-lactmases: groups 1, 2a, 2b, and 2b'. Antimicrob Agents Chemother. 1989a; 33(3): 264-270.

Bush K. Classification of $\beta$-lactmases: groups $2 \mathrm{c}, 2 \mathrm{~d}$, 2e, 3 and 4. Antimicrob Agents Chemother. 1989b; 33(3): 271-276.

Bush K. Metallo- $\beta$-lactamases: a class apart. Clin Infect Dis. 1998; 27(Supplement 4): S48-S53.

Bush K, Jacoby GA, Medeiros AA. A functional classification scheme for $\beta$-lactmases and its correlation with molecular structure. Antimicrob Agents Chemother. 1995; 39(6): 1211-1233.

Bush K, Macalintal C, Rasmussen BA, Lee VJ, Yang Y. Kinetic interactions of tazobactam with $\beta$ lactamases from all major structural classes. Antimicrob Agents Chemother. 1993; 37(4): 851-858.

Concha NO, Rasmussen BA, Bush K, Herzberg O. Crystal structure of the wide-spectrum binuclear zinc $\beta$-lactamase from Bacteroides fragilis. Structure. 1996; 4(7): 823-836.

Cricco JA, Orellano EG, Rasia RM, Ceccarelli EA, Vila AJ. Metallo- $\beta$-lactamase: does it take two to tango. Coordin Chem Rev. 1999; 190-192: 519-535.

Crowder MW, Wang Z, Franklin SL, Zovinka EP, Benkovic SJ. Characterization of the metal-binding sites of the $\beta$-lactamase from Bacteroides fragilis. Biochemistry. 1996; 35(37): 12126-12132.
Crowder MW, Walsh TR. Metallo- $\beta$-lactamases: structure and function. Res Signpost. 1999; 3: 105132.

Payne DJ. Metallo- $\beta$-lactamases: a new therapeutic challenge. J Med Microbiol. 1993; 39(2): 93-99.

Periyannan GR, Costello AL, Tierney DL, Yang KW, Bennett B, Crowder MW. Sequential binding of cobalt(II) to metallo- $\beta$-lactamase CcrA. Biochemistry. 2006; 45(4): 1313-1320.

Rasmussen BA, Bush K. Carbapenem-hydrolyzing $\beta$ lactamases. Antimicrob Agents Chemother. 1997; 41(2): 223-232.

Rasmussen BA, Bush K, Tally FP. Antimicrobial resistance in Bacteroides. Clin Infect Dis. 1993; 16(Supplement 4): S390-S400.

Rasmussen BA, Yang Y, Jacobus N, Bush K. Contribution of enzymatic properties, cell permeability, and enzyme expression to microbiological activities of $\beta$-lactams in three Bacteroides fragilis isolates that harbor a metallobeta-lactamase gene. Antimicrob Agents Chemother. 1994; 38(9): 2116-2120.

Tipper DJ. Mode of action of $\beta$-lactam antibiotics. Clin Infect Dis. 1979; 1(1): 39-53.

Wang Z, Benkovic SJ. Purification, characterization, and kinetic studies of a soluble Bacteroides fragilis metallo- $\beta$-lactamase that provides multiple antibiotic resistance. J Biol Chem. 1998; 273(35): 2240222408.

Yanchak MP, Taylor RA, Crowder MW. Mutational analysis of metallo- $\beta$-lactamase CcrA from Bacteroides fragilis. Biochemistry. 2000; 39(37): 11330-11339.

Yang Y, Rasmussen BA, Bush K. Biochemical characterization of the metallo- $\beta$-lactamase CcrA from Bacteroides fragilis TAL3636. Antimicrob Agents Chemother. 1992; 36(5): 1155-1158.

Received: August 01, 2012 Accepted: July 02, 2013. 